\title{
INSTRUMENTAL RATIONALITY AND GENERAL DETERRENCE
}

\author{
COLTON FEHR ${ }^{*}$
}

\begin{abstract}
The Supreme Court of Canada concluded in R. v. Nur that the use of general deterrence in sentencing is not "rationally connected"to its objective of lowering crime levels. Although this conclusion was drawn in the Charter section 1 context, its logic applies with equal force at the section 7 stage of analysis. As a law bearing no rational connection to its purpose is arbitrary, the author contends that judicial reliance on general deterrence in sentencing runs afoul of section 7 of the Canadian Charter of Rights and Freedoms. This conclusion is significant not only because it would forestall judicial use of general deterrence, but also for what it reveals about the relationship between the instrumental rationality principles. Commentators maintain that the Supreme Court's "individualistic" approach to instrumental rationality resulted in the arbitrariness principle becoming subsumed by overbreadth. Yet, challenging the general deterrence provisions with overbreadth is not possible given the discretion given to judges to avoid its unnecessary application. The fact that a law can be arbitrary but not overbroad provides support for the Supreme Court's insistence upon keeping the principles distinct. It also, however, requires that the Supreme Court adjust its position with respect to its method for proving arbitrariness.
\end{abstract}

\section{TABLE OF CONTENTS}

I. INTRODUCTION . . . . . . . . . . . . . . . . . . . . . . . 53

II. General DeterRence THEORY $\ldots \ldots \ldots \ldots \ldots \ldots \ldots \ldots \ldots \ldots \ldots 6$

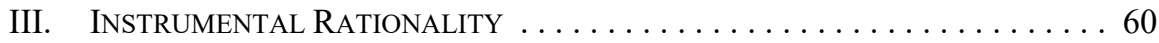

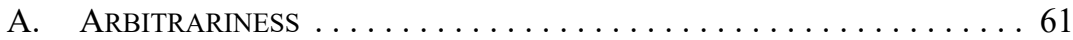

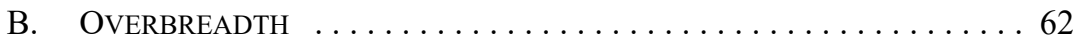

C. ApPlication to Mandatory Minimum Punishments . . . . . . . 62

IV. RATIONALIZING INSTRUMENTAL RATIONALITY $\ldots \ldots \ldots \ldots \ldots \ldots \ldots . \ldots 6$

V. REVIVING GenERAL DETERRENCE . . . . . . . . . . . . . . . . . . 66

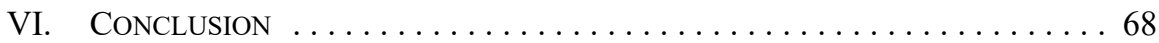

\section{INTRODUCTION}

The principle of deterrence in sentencing found in section 718(b) of the Criminal Code allows courts to impose increased sanctions "for the purpose of discouraging the offender and others from engaging in criminal conduct."1 Deterrence therefore operates on two levels - to deter the offender (specific deterrence) as well as to deter others (general deterrence). ${ }^{2}$ With respect to the latter operation, the offender's sentence is not increased because of just deserts. ${ }^{3}$ Instead, the sentence is increased "because the court decides to send a message to others who may be inclined to engage in similar criminal activity." In this way, the offender is used as a means to achieve a broader policy goal of crime prevention.

PhD candidate and sessional instructor at the University of Alberta, Faculty of Law. The author wishes to thank Annalise Acorn for her insightful comments on a previous draft of this article.

RSC 1985, c C-46. See $R v B W P ; R v B V N, 2006$ SCC 27 at para 2 [BWP].

Ibid.

Ibid.

Ibid. 
Social scientists have been questioning the efficacy of general deterrence theory for decades. ${ }^{5}$ Although the potential of being caught and receiving some punishment likely deters many people from committing crime, ${ }^{6}$ the proposition that increases in sentence severity are linked with decreased levels of crime is far less intuitive. ${ }^{7}$ The mounting academic and judicial skepticism surrounding the merits of general deterrence was recently endorsed by the Supreme Court of Canada in R. v. Nur. ${ }^{8}$ In considering whether a mandatory minimum sentence was capable of effecting general deterrence, the Supreme Court concluded that there is at best a frail connection between the two. ${ }^{9}$ As a result, the mandatory minimum sentence at issue was found not to be rationally connected to the general deterrence principle. $^{10}$

The language used in Nur implicates the "means-ends" or "instrumental rationality" principles of fundamental justice. ${ }^{12}$ One of these principles - known as the arbitrariness principle - prohibits laws that deny life, liberty, or security of the person in a manner that bears no relation to the impugned law's objective..$^{13}$ In other words, "[t]here must be a rational connection between the object of the measure that causes the s. 7 deprivation, and the limits it imposes on life, liberty, or security of the person." "If it is correct that there is no reasonable basis to conclude that increasing sentence severity deters crime, the inclusion of general deterrence among the sentencing principles in the Criminal Code must run afoul of the arbitrariness principle.

This argument is significant for two reasons. First, it would effectively forestall judicial reliance on general deterrence in sentencing. As arbitrary laws are inherently bad, ${ }^{15}$ it is unlikely that the general deterrence provision would be upheld under section 1 of the Canadian Charter of Rights and Freedoms. ${ }^{16}$ Second, the constitutional argument can shed light on a conundrum that commentators have identified with the Supreme Court's "individualistic" approach to instrumental rationality. ${ }^{17}$ Under this approach, courts are to evaluate whether a law applies in an arbitrary, overbroad, or grossly disproportionate manner to a single individual. To facilitate this analysis, the Supreme Court precluded reliance upon

\section{See Part II, below.}

6 See Anthony N Doob \& Cheryl Marie Webster, "Sentence Severity and Crime: Accepting the Null Hypothesis" (2003) 30 Crime \& Justice 143 at 144-46 [Doob \& Webster, "Sentence Severity"]; Raymond Paternoster, "How Much Do We Really Know about Criminal Deterrence?" (2010) 100:3 J Crim L \& Criminology 765 at 789-800 [Paternoster, "Criminal Deterrence"].

$7 \quad$ See Doob \& Webster, "Sentence Severity," ibid at 146. Although one might say that an increase in penalty from a fine of one dollar to the death penalty would generally deter, such hypothetical increases in penalty are far outside the range of those contemplated in Western democracies.

2015 SCC 15 at para 114 [Nur]. The literature will be reviewed below.

Ibid at para 115 .

Ibid at paras 114-15.

Hamish Stewart, Fundamental Justice: Section 7 of the Canadian Charter of Rights and Freedoms (Toronto: Irwin Law, 2012) at 151.

See Canada (Attorney General) v Bedford, 2013 SCC 72 [Bedford].

Ibid at para 111 .

Ibid.

Nur, supra note 8 at paras 114-15. The Supreme Court concluded in Nur that arbitrary laws would fail the "rational connection" branch of the proportionality analysis developed in $R v$ Oakes, [1986] 1 SCR 103 at $135-42$.

16 Part I of the Constitution Act, 1982, being Schedule B to the Canada Act 1982 (UK), 1982, c 11 [Charter].

Hamish Stewart, "Bedford and the Structure of Section 7" (2015) 60:3 McGill LJ 575 at 587 [Stewart,

"Section 7"]; Colton Fehr, "The 'Individualistic' Approach to Arbitrariness, Overbreadth, and Gross Disproportionality" (2018) 51:1 UBC L Rev 55. 
evidence at the section 7 stage about the extent to which the law can achieve its purpose. ${ }^{18}$ Such evidence, the Supreme Court concluded, is to be considered at the section 1 stage of the analysis. ${ }^{19}$

Although this approach ensures litigants are not overburdened at the section 7 stage, ${ }^{20}$ it also raises the question: how can a law be arbitrary if the effects of the law are presumed to be achieved at the section 7 stage ${ }^{21}$ I have elsewhere suggested that this inconsistency would likely not matter as the Supreme Court's new understanding of the overbreadth principle will cover all cases that might have previously been addressed with arbitrariness. ${ }^{22}$ As a law need only apply in an arbitrary manner to a single individual to be overbroad, ${ }^{23}$ this conclusion had some intuitive appeal. ${ }^{24}$ However, deeper reflection suggests this view is subject to exception. A law such as the general deterrence provision is inherently bad due to its unproven ability to effectuate its purpose. However, as judges have discretion as to whether to apply general deterrence, the law is not overbroad as it need not actually catch conduct that is divorced from its objective.

The questionable constitutional status of the general deterrence provision requires that the doctrinal problems created by the Supreme Court's new approach to breaches of instrumental rationality be addressed. To do so, I contend that it is necessary to resort to the old method when proving breaches of the arbitrariness principle. Although this method may require litigants to submit some evidence about the efficacy of a law, in practice this will not overburden litigants. As the government faces the same "arbitrariness" question under the rational connection test of section 1 of the Charter, I maintain that the structure of the Charter will result in the burden of proof effectively being shared in all instances where breaches of the arbitrariness principle may feasibly be pleaded.

The article unfolds as follows. Part II reviews the literature casting doubt upon the efficacy of general deterrence theory. Part III applies this literature to the Supreme Court's individualistic conception of the instrumental rationality principles. In so doing, I illustrate why the general deterrence provision is arbitrary but not overbroad. Part IV then explains the significance of this conclusion for the structure of section 7 of the Charter. Although my conclusion provides support for the Supreme Court's insistence on keeping the arbitrariness and overbreadth principles distinct, it also illustrates why the Supreme Court will be required to readjust its approach to proving arbitrariness. Part V concludes by considering whether a simple revision to the general deterrence provision could nevertheless survive Charter scrutiny.

See Bedford, supra note 12 at para 123; Stewart, "Section 7," ibid at 587; Fehr, ibid at 59.

Bedford, ibid at paras 93-123.

Ibid at para 127. I explain this point in more detail below.

See Stewart, "Section 7," supra note 17 at 587; Fehr, supra note 17 at 59.

See Fehr, ibid at 64-65. It is also notable that Stewart does not attempt to explain how a law might satisfy the overbreadth principle, but violate the arbitrariness principle (Stewart, "Section 7," ibid).

See Bedford, supra note 12 at paras 112-13.

See Fehr, supra note 17 at 64-65. 


\section{General DeterRence Theory}

General deterrence theory, and deterrence theory more broadly, traces its roots to the Enlightenment philosophy of Cesare Beccaria ${ }^{25}$ and Jeremy Bentham. ${ }^{26}$ Beccaria maintained that the motivation to commit crime derived from the inherent tendency of every person to act in their own self-interest. ${ }^{27}$ In other words, if commission of a crime was viewed by an individual to be beneficial, Beccaria maintained that individuals would likely commit the crime. The most suitable means for responding to such self-interested action was to provide offsetting punishments. ${ }^{28}$ However, Beccaria also recognized that an increase in punishment by itself would often fail to deter crime. Although he provided no empirical evidence in support of this view, he surmised that it was more important that punishment be certain and temporally connected to the commission of the crime than severe. ${ }^{29}$

Two decades later, Bentham built upon Beccaria's work by providing a more developed theory of how people make decisions. Providing the foundation for modern-day rational choice theory, ${ }^{30}$ Bentham observed that people make choices by calculating the potential pleasures and pains of opposing options. ${ }^{31}$ Unlike Beccaria, however, Bentham developed a complex set of considerations for determining what would weigh on the "pleasure" and "pain" sides of the equation..$^{32}$ In so doing, Bentham also recognized that individuals would identify pleasures and pains in a highly subjective manner. As such, what might deter one person may not deter another person and vice versa. ${ }^{33}$

Despite the work of Beccaria and Bentham, general deterrence theory became dormant over the next two centuries. Criminologists instead became preoccupied with crime reduction theories focusing on biological determinants of crime. ${ }^{34}$ In dismissing general deterrence theory, Hans von Hentig echoed contentions representative of the thinking at the time. ${ }^{35}$ As he observed, Bentham's appeal to utility maximization "appear[s] to be unreal and simpleminded, when we think of the enormous multiformity and complication of life." ${ }^{36}$ More directly, Hentig believed that general deterrence theory was unsound because the pleasures derived from committing a criminal act are "near object[s]" while the pains derived from

Cesare Beccaria, On Crimes and Punishments, translated by Henry Paolucci (Indianapolis: BobbsMerrill, 1963). The original was published in 1764.

Jeremy Bentham, The Principles of Morals and Legislation (Buffalo: Prometheus Books, 1988). The original was published in 1789 .

See Beccaria, supra note 25 at 12: "[s]ome tangible motives had to be introduced, therefore, to prevent the despotic spirit, which is in every man, from plunging the laws of society into its original chaos. These tangible motives are the punishments established against infractors of the laws." Ibid.

Ibid at 55-59.

See Gary S Becker, The Economic Approach to Human Behavior (Chicago: University of Chicago Press, 1976).

Bentham, supra note 26 at 1.

See ibid at 25. Bentham identified four types of pleasures/pains: physical, political, moral, and religious. Ibid at 43.

See Paternoster, "Criminal Deterrence," supra note 6 at 772-73, citing Nicole Rafter, The Criminal Brain: Understanding Biological Theories of Crime (New York: New York University Press, 2008) at 19-21.

See Hans von Hentig, “The Limits of Deterrence” (1938) 29:4 J Crim L \& Criminology 555. Ibid at 560 . 
being punished are a "long-distance danger." 37 Similar rejection of deterrence theory persisted with very little protest well into the mid-twentieth century. ${ }^{38}$

Several authors nevertheless began to revive general deterrence theory in the mid-1950s and 1960s. ${ }^{39}$ Returning to the thinking of Beccaria and Bentham, these authors set the stage for a research agenda that persisted for the next several decades. As John Ball observed, general deterrence theorists faced two central empirical challenges. First, it would be necessary to separate any deterrent effect arising from the certainty of punishment from the severity of punishment. ${ }^{40}$ Second, it would be necessary to draw a link between the objective and perceptual properties of punishment. In other words, general deterrence theorists must prove that those subject to the general deterrent effect knew about the potentially deterring law. ${ }^{41}$ Clarence Ray Jeffery agreed with these observations but reiterated a third challenge: proving that the low celerity of criminal punishment would not inhibit potential offenders from weighing the various costs and benefits of committing crime. ${ }^{42}$

These earlier calls for greater empirical research were eventually answered in 1968 by Gary Becker ${ }^{43}$ and Jack Gibbs. ${ }^{44}$ Other authors soon followed, igniting a widespread debate about whether the general deterrent effect in sentencing could be proven empirically. ${ }^{45}$ Reviewing the available literature 20 years later, the Canadian Sentencing Commission concluded that it is "extremely doubtful" whether using general deterrence as a sentencing principle could achieve its stated goal of lowering crime rates. ${ }^{46}$ Although the Commission recognized that criminal prohibitions generally have some deterrent effect on would-be offenders, it found that there was little empirical foundation to conclude that increases in the severity of sentences would have the same effect. ${ }^{47}$

Although these initial research failures drew calls for more studies, ${ }^{48}$ the continued failure to affirmatively prove that increases in sentences lowered levels of crime was met with

Ibid at 559 [emphasis omitted].

See Jackson Toby, "Is Punishment Necessary?” (1964) 55:3 J Crim L, Criminology \& Police Science 332 at 333-34; James B Appel and Neil J Peterson, "What's Wrong with Punishment?" (1965) 56:4 J Crim L, Criminology \& Police Science 450 at 452-53.

See e.g. Johs Andenaes, “General Prevention - Illusion or Reality?” (1952) 43:2 J Crim L, Criminology \& Police Science 176 at 193, 197; John C Ball, "The Deterrence Concept in Criminology and Law" (1955) 46:3 J Crim L, Criminology \& Police Science 347 at 347-51.

See Ball, ibid at 351.

Ibid.

CR Jeffery, "Criminal Behavior and Learning Theory" (1965) 56:3 J Crim L, Criminology \& Police Science 294 at 299.

Gary S Becker, "Crime and Punishment: An Economic Approach" (1968) 76:2 J Political Economy 169. Jack P Gibbs, "Crime, Punishment, and Deterrence" (1968) 48:4 Southwestern Soc Science Q 515. See e.g. Franklin E Zimring \& Gordon J Hawkins, Deterrence: The Legal Threat in Crime Control (Chicago: University of Chicago Press, 1973); Jack P Gibbs, Crime, Punishment, and Deterrence (New York: Elsevier, 1975); Raymond Paternoster, "The Deterrent Effect of the Perceived Certainty and Severity of Punishment: A Review of the Evidence and Issues" (1987) 4:2 Justice Q 173; Daniel S Nagin, "Criminal Deterrence Research at the Outset of the Twenty-First Century" (1998) 23 Crime \& Justice 1 [Nagin, "Criminal Deterrence Research"].

Canadian Sentencing Commission, Sentencing Reform: A Canadian Approach (Ottawa: CSC, 1987) at 136-37. The Supreme Court has cited these conclusions approvingly (Nur, supra note 8 at para 113). Canadian Sentencing Commission, ibid.

See Doob \& Webster, "Sentence Severity," supra note 6 at 145-46, citing Andrew Von Hirsch et al, Criminal Deterrence and Sentence Severity: An Analysis of Recent Research (Oxford: Hart, 1999) at 47; Daniel Nagin, "Deterrence in the Twenty-First Century" (2013) 42:1 Crime \& Justice 199. 
significantly more skepticism near the turn of the century. ${ }^{49}$ As Cheryl Webster and Anthony Doob conclude in a recent literature review: "Despite enormous research efforts, no credible and consistent body of evidence has been found to support the conclusion that harsher sentences ... achieve marginal deterrent effects on crime. ${ }^{, 50}$ As such, the authors conclude that it is time to accept the "null hypothesis." ${ }^{11}$ Put differently, it is recommended that the default position be that there is no relationship between increases in sentence severity and lower crime levels.

Webster and Doob defended their position by surveying how the various research efforts to identify a general deterrent effect falter on methodological, statistical, and conceptual grounds. ${ }^{52}$ Several studies conflate lower levels of crime resulting from the incapacitation of repeat offenders with that relating to increased severity of punishment. ${ }^{53}$ Others assume that deterrence is the only rationale that could explain the results of their studies. ${ }^{54}$ As a result, several researchers failed to control for other variables such as changes in social conditions and increases in the presence of law enforcement. ${ }^{55}$ Still others applied ill-conceived studies

Ibid. See also Cheryl Marie Webster \& Anthony N Doob, "Searching for Sasquatch: Deterrence of Crime Through Sentence Severity" in Joan Petersilia \& Kevin R Reitz, eds, The Oxford Handbook of Sentencing and Corrections (New York: Oxford University Press, 2012) 173 [Webster \& Doob, "Searching"]; Michael Tonry, "The Mostly Unintended Effects of Mandatory Penalties: Two Centuries of Consistent Findings" (2009) 38:1 Crime \& Justice 65; Anthony N Doob \& Carla Cesaroni, "The Political Attractiveness of Mandatory Minimum Sentences" (2001) 39:2/3 Osgoode Hall LJ 287; Travis C Pratt et al, "The Empirical Status of Deterrence Theory: A Meta-Analysis" in Francis T Cullen, John Paul Wright \& Kristie R Blevins, eds, Taking Stock: The Status of Criminological Theory, vol 15 (New York: Routledge, 2017); Vincent Schiraldi \& Tara-Jen Ambrosio, "Striking Out: The Crime Control Impact of 'Three-Strikes' Laws" (Washington, DC: Justice Policy Institute, 1997); Michael Tonry, Sentencing Matters (New York: Oxford University Press, 1996) at 137; Lisa Stolzenberg \& Stewart J D'Alessio, “'Three Strikes and You're Out': The Impact of California's New Mandatory Sentencing Law on Serious Crime Rates" (1997) 43:4 Crime \& Delinquency 457; Tamasak Wicharaya, Simple Theory, Hard Reality: The Impact of Sentencing Reforms on Courts, Prisons, and Crime (Albany: State University of New York Press, 1995); Office of National Drug Control Policy, "Relations Between Increases in the Certainty, Severity and Celerity of Punishment for Drug Crimes and Reductions in the Level of Crime, Drug Crime, and the Effects of Drug Abuse" by David P Cavanagh (Los Angeles, BOTEC Analysis Corporation, 1993); Neil Morgan, "Mandatory Sentences in Australia: Where Have We Been and Where Are We Going?" (2000) 24:3 Crim LJ 164; Dan Waldorf \& Sheigla Murphy, "Perceived Risks and Criminal Justice Pressures on Middle Class Cocaine Sellers" (1995) 25:1 J Drug Issues 11; Kimberly N Varma \& Anthony N Doob, "Deterring Economic Crimes: The Case of Tax Evasion" (1998) 40:2 Can J Criminology 165; Robert MacCoun \& Peter Reuter, "Drug Control" in Michael Tonry, ed, The Handbook of Crime and Punishment (New York: Oxford University Press, 1998) 207; Peter Greenwood et al, "Estimated Benefits and Costs of California's New MandatorySentencing Law" in David Shichor \& Dale K Sechrest, eds, Three Strikes and You're Out: Vengeance as Public Policy (Thousand Oaks, Cal: Sage Publications, 1996) 53.

$50 \quad$ Webster \& Doob, "Searching," ibid at 174.

51 Doob \& Webster, "Sentence Severity," supra note 6 at 187 . They reiterated this position more recently in Webster \& Doob, "Searching," ibid at 174. See also Paternoster, "Criminal Deterrence," supra note 6 at $818-23$.

$52 \quad$ See Doob \& Webster, "Sentence Severity," ibid at 155-73.

53 Ibid at 156-57, responding to Steven D Levitt, "The Effect of Prison Population Size on Crime Rates: Evidence from Prison Overcrowding Litigation" (1996) 111:2 QJ Economics 319 [Levitt, "The Effect of Prison"]; Thomas B Marvell \& Carlisle E Moody, Jr, "Prison Population Growth and Crime Reduction" (1994) 10:2 J Quantitative Criminology 109; Richard A Wright, "In Support of Prisons" in Barry W Hancock \& Paul M Sharp, eds, Criminal Justice in America: Theory, Practice and Policy (Upper Saddle River, NJ: Prentice Hall, 1996) 252. Levitt, for instance, contended that a statewide policy of terminating sentences early (due to overcrowding) was causally connected to a subsequent rise in crime levels. As Doob and Webster observe, however, such a position conflates incapacitation deterrence and sentence severity deterrence. In short, the perception that jails were too crowded to take in new offenders is better able to explain these rises in crime rates. For a similar critique, see Nagin, "Criminal Deterrence Research," supra note 45; Von Hirsch et al, supra note 48.

54 See Doob \& Webster,"Sentence Severity," ibid at 156-62, responding to Levitt, "The Effect of Prison," ibid; US, Department of Justice, Crime and Justice in the United States and in England and Wales, 1981-96 by Patrick A Langan \& David P Farrington (Washington, DC: DOJ, 1998). Ibid. 
to support the efficacy of general deterrence ${ }^{56}$ or drew conclusions from highly questionable data. ${ }^{57}$ The literature also does not show anything approaching consistent findings. ${ }^{58}$

Perhaps most importantly, however, is the lack of evidence linking the objective and perceptual elements of punishment. As Richard Paternoster recently observed, despite knowledge of increases in penalties being among "the most crucial links in the deterrence process, it is the one that we know the least about." 59 The limited studies have shown that the public does not know about changes in sentence severity, and even inmates have scant knowledge of when punishments are increased. ${ }^{60}$ Proponents of deterrence theory have been aware of this problem for many years. ${ }^{61}$ Their inability to provide reliable and consistent evidence showing that potential offenders are aware of increases in penalties provides a critical barrier for proving any general deterrent effect arising from increases in sentence severity.

This point applies a fortiori when the ability of judicial increases in sentences to deter others from committing crime is compared to legislative attempts to do the same. Many of the studies investigating the general deterrent effect cited above were conducted in the context of highly publicized legislative policies such as mandatory minimum sentences or the notorious "three strikes" law applied in several American states. ${ }^{62}$ Potential offenders are more likely to know of increases in sentence severity if the policy is highly publicized. Unpredictable and sporadic use of general deterrence in courtrooms across the country is significantly less likely to be known by potential offenders, let alone acted upon. ${ }^{63}$

56 See Doob \& Webster, "Sentence Severity," supra note 6 at 162-63, responding to Steven Klepper \& Daniel Nagin, "Tax Compliance and Perceptions of the Risks of Detection and Criminal Prosecution" (1989) 23:2 L \& Soc'y Rev 209. Although this study was widely criticized for conflating severity and certainty of punishment (see Von Hirsch et al, supra note 48 at 35; Cavanagh, supra note 49 at 41), Doob and Webster also criticize this study's design. "Scenario" studies do not come close to simulating real life situations, and thus are of lesser reliability because they only test how subjects "feel" they would act, not how they actually act. The study was also problematic because its subjects were university students who do not fit the profile of the majority of criminals.

57 See Doob \& Webster, "Sentence Severity," supra note 6 at 164-67, responding to Daniel Kessler \& Steven D Levitt, "Using Sentence Enhancements to Distinguish Between Deterrence and Incapacitation" (1999) 42:1 JL \& Econ 343; Steven D Levitt, "Deterrence" in James Q Wilson \& Joan Petersilia, eds, Crime: Public Policies for Crime Control (Oakland, Cal: Institute for Contemporary Studies, 2002) 435. These authors rely on a study attempting to separate the severity of incapacitation factor from severity of punishment. The study concerned a 1982 referendum in California that opted to raise the punishments for certain severe crimes. The authors then compared that data to six crimes not affected by the referendum. Not only is there no reason to expect short-term changes in one set of crimes to move in the same direction as the other, the study skips over some years with only minimal explanation. The problem remained that there was no way of telling exactly what trends were continuing, being reversed, or neutralized.

58 See Doob \& Webster, "Sentence Severity," ibid at 167-70.

$59 \quad$ Paternoster, "Criminal Deterrence," supra note 6 at 805.

$60 \quad$ Ibid, citing Zimring \& Hawkins, supra note 45 at 143; David A Anderson, "The Deterrence Hypothesis and Picking Pockets at the Pickpocket's Hanging" (2002) 4:2 Am L \& Econ Rev 295 at 305; Neal Shover, Great Pretenders: Pursuits and Careers of Persistent Thieves (Boulder: Westview Press, 1996) at 151-74; Kenneth D Tunnell, Choosing Crime: The Criminal Calculus of Property Offenders (Chicago: Nelson-Hall, 1992) at 60-85; Richard T Wright \& Scott H Decker, Burglars on the Job: Streetlife and Residential Break-Ins (Boston: Northeastern University Press, 1994) at 127-33; Richard T Wright \& Scott H Decker, Armed Robbers in Action: Stickups and Street Culture (Boston: Northeastern University Press, 1997) at 59-60.

${ }_{61}$ See e.g. Steven D Levitt, "Why Do Increased Arrest Rates Appear to Reduce Crime: Deterrence, Incapacitation, or Measurement Error?” (1998) 36:3 Economic Inquiry 353 at 353.

62 The three strikes policy generally holds that offenders who commit three (typically felony) offences will be jailed for life after the third crime.

${ }_{63}$ See Doob \& Webster, "Sentence Severity," supra note 6 at 173, citing Philip J Cook, "Research in Criminal Deterrence: Laying the Groundwork for the Second Decade" (1980) 2 Crime \& Justice 211. 
Compounding these difficulties is the fact that the criminal justice system is ill-equipped to provide prompt punishment. Liberal democracies tend to provide their citizens with many procedural rights, such as the right to a fair trial and the right to speak to counsel. Facilitating these rights inevitably slows the course of justice. ${ }^{64}$ Yet, delaying punishment is prone to lead to misapprehension of the actual costs of committing a crime. Studies show, for instance, that people who have previously served prison time would view a distant ten-year sentence as significantly less than twice as severe as an impending five-year sentence. ${ }^{65}$ Behavioral economists and psychologists refer to this discounting as the "pain of paying." researchers conclude that the reason people use credit cards to purchase items they cannot afford is because it is difficult to immediately feel the "pain" of making a purchase. ${ }^{67}$ The fact that social scientists "know virtually nothing about celerity" 68 in the sentencing context makes it increasingly difficult to prove that increases in sentence severity actually deter crime.

Despite important calls for research into the question of whether increases in sentence severity deter crime, the available evidence in support is thin. It is unlikely that criminal defendants know about increases in punishment. For those that possess such knowledge, it remains unclear whether it is the threat of getting caught or the increase in sentence severity that causes any potential deterrent effect. Moreover, research does not show that the deterrent effect is unhindered by the lag in imposing sanctions inherent in liberal criminal justice systems. The Supreme Court's implicit acceptance of these points in Nur underpins its conclusion that increases in sentence severity are not rationally connected to lowering levels of crime. This raises the question: is the inclusion of general deterrence as a sentencing principle in the Criminal Code consistent with section 7 of the Charter?

\section{INSTRUMENTAL RATIONALITY}

Section 7 of the Charter provides that "[e]veryone has the right to life, liberty and security of the person and the right not to be deprived thereof except in accordance with the principles of fundamental justice. ${ }^{\circ 9}$ In other words, if a law engages the life, liberty, or security of the person interests of any individual, it must do so in accordance with the principles of fundamental justice. ${ }^{70}$ The availability of imprisonment for an offence is sufficient to engage the liberty interest. ${ }^{71}$ As a result, it is reasonable to conclude that the ability of the general deterrence principle to increase imprisonment terms engages the liberty interest. ${ }^{72}$ The issue, then, is whether this deprivation of liberty accords with the principles of fundamental justice.

See Paternoster, "Criminal Deterrence," supra note 6 at 821-22.

Ibid, citing Kent A McClelland \& Geoffrey P Alpert, "Factor Analysis Applied to Magnitude Estimates of Punishment Seriousness: Patterns of Individual Differences" (1985) 1:3 J Quantitative Criminology 307 at 311. This study builds on earlier observations (Cook, supra note 63 at 232-33).

See Brian Knutson et al, "Neural Predictors of Purchases" (2007) 53:1 Neuron 147 at 147; Scott I Rick, Cynthia E Cryder \& George Loewenstein, "Tightwads and Spendthrifts" (2008) 34:6 J Consumer Research 767 at 768 .

See Knutson et al, ibid at 151-52; Rick, Cryder \& Loewenstein, ibid at 767-69.

Paternoster, "Criminal Deterrence," supra note 6 at 818.

Supra note 16.

See $R v$ Morgentaler, [1988] 1 SCR 30 at 52.

See $R v$ Malmo-Levine; $R v$ Caine, 2003 SCC 74 at para 84.

See $B W P$, supra note 1 at para 2 . 


\section{A. Arbitrariness}

For a law to run afoul of the arbitrariness principle, there must not be a rational connection between the objective of the law and the limit it imposes on an offender's protected interests. ${ }^{73}$ The applicant may demonstrate arbitrariness in two ways. First, the applicant may show that the law's effect actually undermines its objective. ${ }^{74}$ I will refer to this as a logical failing of instrumental rationality. Second, the applicant may show that there is no evidentiary connection between the law's effect and its objective. ${ }^{75}$ I will refer to this as an empirical failing of instrumental rationality. It follows that a law need not be internally inconsistent to violate the arbitrariness principle; merely pointing to an absence of a factual foundation that the law furthers its purpose is sufficient to prove a breach of the arbitrariness principle. As with any claim that a law violates Charter rights, the applicant must prove an infringement on a balance of probabilities. ${ }^{76}$

As outlined in Part II, there are several reasons why it is difficult to find an empirical connection between increases in sentence severity and lower levels of crime. First, and most importantly, the evidence suggests that people do not know of increases in sentence severity. ${ }^{77}$ Although scholars have come to this conclusion in the context of legislative uses of general deterrence such as mandatory minimum sentences, it is important to reiterate that potential offenders are even less likely to know of judicial applications of general deterrence in sentencing. ${ }^{78}$ Second, it is questionable whether it is the threat of being caught and punished that deters as opposed to the chance of receiving an increased sentence. ${ }^{79}$ Finally, it is unclear how the lack of celerity in punishment impacts offender perceptions. If offenders give little weight to "distant" criminal punishment, the criminal justice system itself may be incapable of exploiting any cost-benefit calculations of potential offenders. ${ }^{80}$

It is possible that one day consistent and reliable findings will be made that support the conclusion that narrow applications of the general deterrence principle reduce crime levels. To date, however, the evidence does not support this conclusion. Moreover, it would take more than the odd study finding some correlation between increases in sentences and lower crime levels to rebut the mounting literature finding no reliable evidence of a general deterrent effect by increasing sentence severity. As Webster and Doob recently reiterated, any "particular finding $[\mathrm{s}]$ of a marginal deterrent effect that has not been replicated across comparable people, offenses, and settings lends little persuasive support to the [efficacy of general deterrence] theory." ${ }^{81}$ Given the existing literature, the Supreme Court of Canada's conclusion in Nur that the general deterrence principle is not rationally connected to its objective of lowering crime levels seems eminently reasonable. ${ }^{82}$

See Bedford, supra note 12 at para 111.

Ibid at para 119 .

Ibid.

See $R v$ Collins, [1987] 1 SCR 265 at 277.

See Part II, above. The argument with fraud is perhaps the strongest as these people's profession arguably makes them more likely to weigh costs and benefits. However, even in this context the evidence is thin. See Varma \& Doob, supra note 49.

See Part II, above.

See Doob \& Webster, "Sentence Severity," supra note 6; Paternoster, "Criminal Deterrence," supra note 6.

See Paternoster, "Criminal Deterrence," ibid at 817-18.

Webster \& Doob, "Searching," supra note 49 at 177.

See Nur, supra note 8 at paras 113-14. 


\section{B. OVERBREADTH}

The overbreadth principle applies when a law is so broad in scope that it catches some conduct that is not rationally connected to the law's objective. ${ }^{83}$ In other words, the law is "arbitrary in part." ${ }^{\prime 4}$ As mentioned above, the individualistic approach to the instrumental rationality principles requires that the law apply in an overbroad manner only to a single individual. ${ }^{85}$ In the case of the general deterrence provision, however, courts have discretion as to when to use the provision to increase a sentence. As such, the section can be interpreted in a manner that avoids overbroad applications of general deterrence. Courts can simply refuse to exercise their discretion to increase the sentence without evidence that the increase in sentence stands a reasonable chance at lowering crime levels.

The context in which the general deterrence provision was added to the Criminal Code provides support for this interpretation. Although skepticism was building about its efficacy when the sentencing regime was passed in 1996 - including doubts expressed by the Canadian Sentencing Commission ${ }^{86}$ - theorists were still optimistic that further study would reveal some conclusive evidence of the efficacy of the general deterrence principle. ${ }^{87}$ As such, Parliament's inclusion of general deterrence among the sentencing principles was reasonable at the time. However, it is unlikely that Parliament intended to allow courts to use the provision carte blanche. Given its awareness of the lack of empirical support for the general deterrence effect in sentencing, Parliament likely intended that courts only apply the principle in instances where some proof of its efficacy was available. In my view, this discretion saves the provision from any overbreadth challenge as courts may refuse to apply the provision when doing so would fail to achieve general deterrence.

The fact that judges may refuse to apply a law is not, however, a good reason to allow an arbitrary law to stay on the books. It is unlikely that courts applying the sentencing regime every day in courtrooms across the country will turn their mind to the efficacy of general deterrence before using it to increase an offender's sentence. Even when Canadian judges were told by Parliament not to apply general deterrence as part of the sentencing reforms to the Youth Criminal Justice Act, ${ }^{88}$ judges still had to be told by the Supreme Court of Canada not to apply the general deterrence principle to young offenders. ${ }^{89}$ This shows how ingrained the principle is in the Canadian criminal justice system. As use of the general deterrence principle is arbitrary, it is better that judges are not tempted with the ability to use it in sentencing as any application would currently violate section 7 of the Charter.

\section{Application to Mandatory Minimum Punishments}

The above constitutional argument applies only to judicial uses of section 718(b) of the Criminal Code to increase a punishment from what would otherwise constitute a

See Bedford, supra note 12 at para 112 .

Ibid [emphasis removed].

Ibid at para 123 .

Supra note 46 at $136-37$.

See the historical review by Doob \& Webster, "Sentence Severity," supra note 6. To my knowledge, Doob and Webster were the first to explicitly call for acceptance of the "null hypothesis."

SC 2002, c 1.

See BWP, supra note 1. 
proportionate sentence. It is much more difficult to isolate the use of general deterrence when considering its other common use: mandatory minimum sentences. Such provisions use general deterrence as one of the rationales for imposing a minimum punishment. As mandatory minimum sentences are enacted to enhance a multitude of sentencing objectives, their application to any given offender cannot be said to be "arbitrary" or "overbroad" in the constitutional sense. In Nur, for instance, although the Supreme Court found that the mandatory minimum punishment for possessing prohibited firearms found in section 95(2)(a) of the Criminal Code was not rationally connected to the general deterrence principle, it had no difficulty finding that it was connected to the sentencing principles of denunciation and retribution. $^{90}$

Where the problematic aspect of a sentencing provision is mixed with other legitimate objectives, the Supreme Court has instead applied the prohibition against cruel and unusual punishment found in section 12 of the Charter. This provision asks whether the punishment imposed is grossly disproportionate to the moral blameworthiness of the offender. ${ }^{91}$ As with the overbreadth principle, if the law applies to even one person in a grossly disproportionate manner, it will violate the Charter..$^{92}$ In Nur, the Supreme Court utilized this principle to strike down the mandatory minimum punishment at issue..$^{93}$ Although the Supreme Court did not rule out the possibility of applying the section 7 instrumental rationality principles to mandatory minimum sentences ${ }^{94}$ it also did not opine upon the circumstances in which section 7 would overtake section 12 of the Charter. ${ }^{95}$

Utilizing section 12 of the Charter to challenge mandatory minimum sentences is preferable given that these provisions balance a variety of complex sentencing principles. It is simply unclear what purpose isolating individual objectives under a section 7 analysis would serve. Finding that a law is not connected to one of its multiple objectives tells the legislature that it could simply repass the same law without the defective objective and the law would be consistent with the arbitrariness/overbreadth principles. Isolating the objectives for individual scrutiny thus serves little purpose as it does not address the core question: is the balance struck by a mandatory minimum provision consistent with the prohibition against cruel and unusual punishment found in section 12 of the Charter? This is not to say that the inefficacy of one of a law's multiple objectives is irrelevant to section 12 analysis. As proportionality analysis weighs the salutary and deleterious effects of a law, the fact that one of the law's supposed salutary effects is unachievable will inevitably affect this calculus. Standing alone, however, such a disconnect between one of a law's objectives and its effect should not result in a breach of section 7 of the Charter.

Section 7 of the Charter does, however, have a role to play in considering the constitutionality of the process underlying sentence determinations. Although proportionality in sentencing has been rejected as a principle of fundamental justice, ${ }^{96}$ this cannot be stretched to mean that individual rationales for increasing punishment are immune from

See Nur, supra note 8 at para 115 .

Ibid at para 39, citing $R \vee$ Smith, [1987] 1 SCR 1045 at 1072-73.

Nur, ibid.

Ibid at paras 78-80.

Ibid at paras $107-10$.

Ibid.

See $R$ v Safarzadeh-Markhali, 2016 SCC 14 at paras 67-73 [Safarzadeh-Markhali]. 
scrutiny for compliance with section 7 . Section 12 is relevant only to the proportionality of the punishment ultimately imposed; the instrumental rationality principles serve the purpose of ensuring that any deprivation of liberty has some rational basis.

\section{RATIONALIZING INSTRUMENTAL RATIONALITY}

The above observations provide a key insight into how one might distinguish arbitrariness and overbreadth under the Supreme Court's individualistic approach to instrumental rationality. If a law breaches the arbitrariness principle because it logically fails to achieve its objective, it must follow that the law will also logically fail to achieve its objective as applied to any individual litigant. In other words, complete logical failures of rationality are divisible into individual failures of logical rationality. A litigant faced with proving that a law fails logically to further its aim to a single individual (overbreadth) as opposed to all individuals (arbitrariness) would reasonably choose the former path as it would require that the state bear the heavier onus of showing that the law possesses some rational connection to its objective (absence of arbitrariness) under the section 1 analysis.

As explained above, however, a law that is arbitrary in the empirical sense will not always be overbroad. The inevitable conclusion is that the arbitrariness principle should only apply to empirical failings of rationality under the Supreme Court's individualistic approach to the instrumental rationality principles. At the least, the arbitrariness principle applies to laws where the government asserts that its law has some sort of effect and then provides judges with discretion as to whether to apply the law. This discretion shields the law from an overbreadth challenge. The fact that courts have discretion not to apply the law cannot, however, save it from an arbitrariness challenge as its mere existence offends the principles of fundamental justice.

The problem remaining for litigants is that under the Supreme Court's new approach to proving breaches of the instrumental rationality principles, it is not possible for applicants to submit evidence as to whether the law actually achieves its objective. Instead, the court hearing the constitutional challenge is to presume that the impugned law's objective is achievable. ${ }^{97}$ As Stewart and I have observed, this makes it impossible to prove that a law is arbitrary. ${ }^{98}$ Indeed, the whole purpose of an arbitrariness analysis is to scrutinize a law to assess whether it has any connection to its objective. ${ }^{99}$

Utilizing the old approach for claims of arbitrariness would alleviate this problem. The previous approach effectively required that the defendant prove that a law failed to satisfy one of the requirements for justifying a law under section 1: arbitrariness substituted for rational connection, overbreadth for minimal impairment, and gross disproportionality for the balancing of a law's deleterious and salutary effects. ${ }^{100}$ Applicants were therefore effectively required to show that the law constituted an inappropriate balance of harms and

See Bedford, supra note 12 at para 123.

See Stewart, "Section 7," supra note 17 at 587; Fehr, supra note 17 at 59. Ibid.

See Fehr, supra note 17 at 55, citing Rodriguez v British Columbia (Attorney General), [1993] 3 SCR 519 at 594-95 [Rodriguez]. 
benefits given the available policy options open to the government. ${ }^{101}$ Such balancing often involves consideration of complex social science evidence, which many litigants simply could not reasonably be expected to call. ${ }^{102}$ As Chief Justice McLachlin observed in Bedford, the individualistic approach prevents such injustice by requiring that litigants only show that a law applied irrationally to one person. ${ }^{103}$

It is unclear, however, why the Supreme Court concluded that a law's objective should be presumed to be achieved in all instances where a law's instrumental rationality is challenged. Such a presumption is sensible, for instance, with respect to applications of the overbreadth principle. Overbreadth challenges typically assess logical failings of rationality. ${ }^{104}$ This type of challenge is not concerned with the ability of the law to achieve its objective; it claims that the effect of the law contradicts its objective in some circumstance. ${ }^{105}$ If the efficacy of a law is typically irrelevant to a plea that a law is overbroad, then sparing the litigant the pains of calling costly evidence to assess the ability of the law to achieve its purpose is sensible. ${ }^{106}$ The government can and should call such evidence to prove that its law achieves an appropriate balance at the section 1 stage of analysis. $^{107}$

Fortunately, proving a breach of the arbitrariness principle in the empirical sense does not raise the same concerns as proving arbitrariness in the logical sense. The former type of proof could feasibly be satisfied by the applicant asking questions that raise doubts about a law's efficacy. In the context of section 718(b) of the Criminal Code, the applicant might ask: Do offenders know of judicial increases in sentences? Is it certainty or severity of punishment that deters? Does a lack of celerity provide a serious barrier to deterring wouldbe offenders? By asking poignant questions that cast sufficient doubt on a law's efficacy, the law could be proven to be arbitrary on a balance of probabilities. The tactical burden would then shift to the Crown under section 1 to show some rational connection between the law's objective and its effects.

This conception of the method for proving arbitrariness is also consistent with the purpose of the Supreme Court's revised approach to breaches of instrumental rationality. Indeed, it is precisely what proving an arbitrariness claim should look like if the idea that applicants

\section{Ibid.}

See Bedford, supra note 12 at para 126. See also Fehr, supra note 17 at $72-73$ (using the voluminous social science evidence called in the Supreme Court's decision in Bedford to illustrate this point). Bedford, ibid at para 123.

To my knowledge, this is true with respect to all applications of the Supreme Court's "individualistic" approach. See $R v$ Michaud, 2015 ONCA 585 at paras 74-75, leave to appeal to SCC refused, 36706 (5 May 2016) (a law requiring a speed limiter on commercial trucks was overbroad because avoiding accidents can at times require increasing speeds greater than the speed limiter would allow, thus endangering public safety contrary to the law's objective); Carter v Canada (Attorney General), 2015 SCC 5 (prohibition against allowing people to access assistance in dying even when they were not considered vulnerable persons); $R \vee$ Appulonappa, 2015 SCC 59 (a prohibition against human smuggling caught instances of humanitarian aid contrary to its objective of punishing those who smuggle humans as part of an organized crime venture); Safarzadeh-Markhali, supra note 96 at paras 52-54 (enhanced sentence credit for pre-trial custody was denied for reasons that had nothing to do with protecting public safety).

Ibid.

It is notable that Stewart and I have identified limited instances where presuming that a law achieves its objective at the section 7 stage could lead to unfair results concerning application of the gross disproportionality principle as well. See Hamish Stewart, "The Constitutionality of the New Sex Work Law" (2016) 54:1 Alta L Rev 69 at 82-83; Fehr, supra note 17 at 61-64.

This was precisely Chief Justice McLachlin's point. See Bedford, supra note 12 at para 126. 
should not be required to demonstrate the inefficacy of a law as it applies to all people is taken seriously. In other words, there is a "sharing" of the burden of proof inherent in any plausible reading of the Bedford understanding of arbitrariness as it relates to section 1 of the Charter. This understanding of arbitrariness is reasonable as it not only carves out a role for arbitrariness vis-à-vis the other instrumental rationality principles, it also avoids the fairness problems identified with the Supreme Court's previous approach to the instrumental rationality principles.

\section{ReViving General DeterRence}

Although the potential for increases in the severity of sentences to lower crime levels remains highly questionable, even leading academics criticizing the merits of general deterrence theory believe consideration of such possibilities should not be entirely abandoned. ${ }^{108}$ This concession opens the door for consideration of alternative remedies to striking down section 718(b) of the Criminal Code. The heart of the problem with section 718(b) is that there is no mandated standard of proof to which potential discoveries of efficacious applications of general deterrence must be subject. Parliament instead left judges to use judicial intuition in applying the general deterrence principle. In my view, reading in a high standard to guide judges as to when to use the general deterrence principle would provide a suitable constitutional remedy.

Section 52 of the Constitution Act, $1982^{109}$ allows courts to fashion a variety of remedies to respond to unconstitutional legislation. In so doing, courts are guided by the requirement that any remedy be imposed only to the "extent of the inconsistency." remedy of reading in words to correct a constitutional defect, the Supreme Court has concluded that such a remedy will be appropriate if the relevant legislature would likely have passed the proposed revision had it known about the constitutional defect. ${ }^{111}$ In adopting such a remedy, courts must be mindful of their constitutional role. It would be less intrusive for a court to strike down legislation and allow for the legislature to devise its own response than for a court to read in words it does not reasonably think the legislature would have enacted. ${ }^{112}$

As discussed above, Parliament passed its sentencing scheme amidst uncertainty not only about the efficacy of general deterrence, but also about the content of section 7 of the Charter. Although the arbitrariness principle had been constitutionalized by 1996 when the sentencing provisions were adopted, its content remained in its infancy. ${ }^{113}$ More importantly, it was still unclear at the time whether studies concerning the use of general deterrence in sentencing would yield some positive results. In my view, it is reasonable to conclude that Parliament would likely respond to the development of the instrumental rationality principles and the increasing skepticism in the literature studying the general deterrence effect in sentencing by imposing a heightened burden of proof before allowing a court to use general deterrence to justify imposing a higher sentence.

\footnotetext{
108 Most notably, see Doob \& Webster, "Sentence Severity," supra note 6 at 189.

109 Being Schedule B to the Canada Act 1982 (UK), 1982, c 11.

Ibid.

See $R v$ Ferguson, 2008 SCC 6 at para 51, citing Schachter $v$ Canada, [1992] 2 SCR 679 at 697.

$R v$ Ferguson, ibid.

See Rodriguez, supra note 100 at 594-95.
} 
If reading in a higher standard of proof is prudent, it becomes necessary to query what standard would be appropriate. The Supreme Court's jurisprudence with respect to proving aggravating factors at the sentencing stage of proceedings provides a useful starting point. As the Supreme Court concluded in R. v. D.B., it is a principle of fundamental justice under section 7 of the Charter that all aggravating factors used to increase an offender's sentence must be proven beyond a reasonable doubt. ${ }^{114}$ The Supreme Court came to this conclusion because aggravating factors have the potential to deprive accused persons of liberty independent of any other sentencing consideration. ${ }^{115}$ The same standard should arguably be applied to uses of general deterrence in sentencing as it also operates independently to deprive persons of liberty.

Yet, aggravating factors are generally not reliant upon complex social science evidence. Instead, aggravating factors often derive from the facts germane to the case. ${ }^{116}$ Given the inherently greater difficulty in proving that increases in sentence severity deter crime, a more relaxed standard should serve as a prudent constitutional remedy. An exemplary provision was recently passed in Israel. ${ }^{117}$ In recognition of the questionable merit of general deterrence theory, the law requires there to be a "serious likelihood" that a judicial increase in sentence severity will lower crime levels before it is applied to increase an offender's sentence. ${ }^{118} \mathrm{In}$ my view, such a standard strikes an appropriate balance between the need to protect accused persons from arbitrarily being deprived of liberty and the need to provide law enforcement with a tool which, although currently inefficacious, could one day be proven to deter some crimes.

Even if the revised law is dormant for many years, it would still serve two main purposes. First, it would require courts to question the efficacy of the general deterrence principle before using it to increase an offender's sentence. Failure to do so would be an error of law. As outlined earlier, it is unlikely that judges turn their minds to the efficacy of general deterrence before routinely applying it in court. ${ }^{119}$ It is this feature of the current law which allows it to be applied in an unprincipled manner. On the other hand, legislatures cannot be expected to predict with certainty when adequate evidence will arise in support of a social effect. Requiring the Crown to prove that general deterrence will be effective in any given scenario strikes a middle ground between these competing considerations.

Second, such a law would encourage more focused study of the efficacy of general deterrence. Testing the theory's merits in general has resulted in unreliable results. Greater and more focused study of narrowly defined examples of crime where judicial intuition has suggested the principle may have application — such as with large-scale frauds, ${ }^{120}$ drinking

2008 SCC 25 at para 78.

Ibid at para 80, citing $R \vee$ Pearson, [1992] 3 SCR 665 at 686.

See Criminal Code, supra note 1, s 718.2(a).

See Israel's Penal Law (Amendment No 113), (2012) 2337 LSI 170, s 40g, translated by Julian V Roberts \& Oren Gazal-Ayal, "Statutory Sentencing Reform in Israel: Exploring the Sentencing Law of 2012" (2013) 46:3 Israel LR 455 at Appendix A.

See Roberts \& Gazal-Ayal, ibid at 463.

See Part III, above.

See $R v$ Gray, 1995 CanLII 18 at 22 (Ont CA). The Court states in the context of a large-scale fraud that "there are few crimes where the aspect of deterrence is more significant. It is not a crime of impulse and is of a type that is normally committed by a person who is knowledgeable and should be aware of the consequences." See also $R v$ Drabinsky, 2011 ONCA 582 at paras 159-60; $R v$ Fulcher, 2007 ABCA 381 at para 44 for similar conclusions. 
and driving, ${ }^{121}$ and sexual abuse of children ${ }^{122}$ — would allow for a more informed understanding of whether judicial increases in sentence severity actually deters crime. If these studies illustrate that certain types of crime under identifiable conditions are likely to benefit from the general deterrent effect, judges could draw analogies to similar types of crime and offenders to give the principle wider application.

\section{Conclusion}

This article has explored two distinct but related issues. The first issue concerns the implications of the Supreme Court's conclusion in Nur that there is no rational connection between increases in sentence severity and lower levels of crime. This conclusion is consistent with the literature assessing the efficacy of the general deterrence principle in sentencing. As the general deterrence provision is not rationally connected to its objective, it must follow that its codification in section 718(b) of the Criminal Code is inconsistent with the principle of fundamental justice prohibiting arbitrary laws. As this breach cannot be justified under section 1 of the Charter, the provision must be declared unconstitutional. This need not mean, however, that general deterrence cannot remain among the sentencing principles in the Criminal Code. The provision can be saved by reading in a requirement that the Crown prove a significant likelihood that application of the general deterrence principle would achieve its aim.

The discussion of the constitutionality of general deterrence is also useful for what it reveals about the Supreme Court's individualistic conception of the instrumental rationality principles. The fact that a law can be both arbitrary and not overbroad provides support for the Supreme Court's insistence upon keeping the principles distinct. It also, however, requires that the Supreme Court reconsider its insistence upon presuming that objectives are achieved at the section 7 stage of analysis. In the context of arbitrariness claims, it is necessary to question the efficacy of a law's objective. Such claims can be fairly litigated as they only require that the applicant raise poignant questions that cast sufficient doubt upon the law's efficacy. This in turn would shift the burden to the state to provide the necessary evidence to justify the law under section 1 of the Charter. In effect, then, the structure of the Charter will ensure that the burden of proving arbitrariness is fairly distributed between applicants and the state. committed by otherwise law-abiding persons, with good employment records and families. Arguably, such persons are the ones most likely to be deterred by the threat of severe penalties." In support of this conclusion, Chief Justice Lamer cites $R v$ McVeigh, 1985 CanLII 115 at 5-6 (Ont CA); $R v$ Biancofiore (1997), 35 OR (3d) 782 at 790-92 (CA); $R \vee$ Blakeley (1998), 40 OR (3d) 541 at 542-43 (CA). It is notable, however, that these cases predate much of the literature cited above. 